\title{
Modern Foreign Languages in Poland
}

\author{
Marcin LĄCZEK \\ Uniwersytet Warszawski/ University of Warsaw \\ E-mail: m.laczek@uw.edu.pl,
}

\begin{abstract}
This text, on its theoretical plane, sketches the differentia specifica existing between Polish (applied) linguistics and didactics (methodology) of foreign language teaching and learning/ glottodidactics as well as probes contexts of teaching the native versus the other (i.e. foreign) language - based on English. After referring to some of the most important works found in the (Polish) literature (all concerned with teaching and learning the English language), in the further part of the article, the author advises on current education system in Poland. The empirical section, in turn, quotes the most recent figures excerpted from the data published by the Central Statistical Office in Poland, and regarding the number of speakers of particular modern foreign languages (based on primary, lower secondary and secondary education in the preceding school year, i.e. 2016-2017).
\end{abstract}

Keywords: modern foreign languages, methodology of foreign language teaching and learning, glottodidactics, Polish system of education, primary education, lower secondary schooling, secondary education

\section{Introduction to Polish (Applied) Linguistics and Glottodidactics}

At the end of the $18^{\text {th }}$ century, a German linguist, August Ferdinand Bernhardi, as the very first scholar ever, distinguishes and then separates applied linguistics from pure linguistics. Second, in chronological order, is Jan Niecisław Ignacy Baudouin de Courtenay of Polish origin. As F. Grucza (2013: 49-50, 185) notes, the date of publication of A. F. Bernhardi's work does not set the start of the history of applied linguistics at all, but merely "(a) the beginning of the history of conscious isolation of applied linguistics and, thus, dividing the general scope of linguistics into pure and applied linguistics; and (b) the beginning of the explicit recognition of certain concepts to the set of objectives of applied linguistics". What is more, the year of giving by J. N. I. Baudouin de Courtenay his famous St. Petersburg lecture - i.e. 1870 - does not, similarly, stand for the beginning of the history of Polish applied (meta)linguistics per se. In fact, F. Grucza (2013: 187) rejects the assertion that the difference between these two subfields is that pure linguistics has only cognitive objectives while applied linguistics - practical, arguing that both are of cognitive nature: "knowledge, and only knowledge creation", be it a different kind of knowledge (F. Grucza 2013: 117). 
Adam Mickiewicz University in Poznan is the place where Polish glottodidactics - termed either "methodology" or "didactics of foreign languages teaching", and perceived by the Poznań linguists as a field of (applied) linguistics - is born. The place where "glottodidactics" is used in a pioneering way though is the Institute of Applied Linguistics of the University of Warsaw. Indeed, F. Grucza (2013: 222) uses it in the title of the first symposium organised by the Institute of Applied Linguistics of the University of Warsaw in 1972: "Applied Linguistics and Glottodidactics". Glottodidactics, F. Grucza (2013: 221-228) states focuses its research interests on scientific comprehension of the processes that operate in the glottodidactic system during the process of language learning. S. Grucza (2013: 6), in turn, adds that glottodidactics, which is established as an independent field of study in the second half of the twentieth century, concentrates on foreign language teaching, foreign language learning and foreign language teachers' education. However, according to W. T. Miodunka (2009: 77-78) "the term glottodidactics works with one limitation: it refers to teaching foreign languages, and not to teaching languages in general (including the mother tongue, as it is originally suggested by Prof. F. Grucza)" As a matter of fact, it is "linguodidactics" which deals with the school acquisition process, the development and improvement of linguistic and communicative competence in the mother tongue/ first language, J. Nocon (2012) claims.

It is important to note that in opposition to the Poznan school of linguistics, which combines glottodidactics not with pedagogy or general didactics but with linguistics, F. Grucza (2013: 223) treats it as "a (relatively) autonomous" field justifying that both linguistics, glottodidactics and general didactics, firstly, work on different subjects and, secondly, "glottodidactics (the sequence of cognitive work that constitutes it must be divided into the stage (plane) of pure research and the stage (plane) of applied (applicative) research." Hence according to the assumptions of the linguists from Adam Mickiewicz University in Poznań, glottodidactics is identical with methodology of teaching foreign languages whereas the conception propagated by the University of Warsaw posits that its main purpose is to study the functioning of one of the particular types (a certain category) of communication systems that F. Grucza (2013: 221) calls "glottodidactic systems":

[t]heir main (constitutive) elements (components) are, on the one hand, pupils and, on the other hand, teachers of languages, but not only of foreign languages, but also mother tongues. The primary objective of glottodidactics is the reconstruction of specific properties (abilities, skills) of both constitutive coefficients of these systems and, thus, not only teachers, but also, as a matter of fact, and in the first instance, pupils involved in such communication systems.

To conclude this part, let me yet expand here in more detail upon the very concept of reconstruction ${ }^{2}$ : learning, assimilation or acquisition S. Grucza (2013: 106), based on the anthropocentric theory, calls "reconstruction" both in reference to a general

${ }^{1}$ All translations from the Polish language are mine, M. $Ł$.

2 J. Sokol (2015), to give another example, replaces "learning" (first) language with its

"constructing" (with assistance of the trial and error method, and adults). 
and specialised idiolect: "[r]econstruction of specialised idiolect, similarly to reconstruction of general idiolect, is based on linguogenerative (biological-genetic) properties of speakers-listeners". Besides, as the author (2013: 145) adds further:

real languages (idiolects) of specific individuals, and, thus, real specialised languages (idiolects) of specific professionals are not something given to anyone 'in advance', that every man has to produce ('acquire') his own language (idiolect) and only he can develop it himself. Second, 'language acquisition' is a process in which every man 'produces' (his own) real language based on a specific kind of biological-genetic linguogenerative properties and that language learning 'involves' the process of generating linguistic knowledge about the world - the process of getting to know the world, that, yet at this level, human languages 'fulfil' important cognitive functions in general, and specialised languages in particular.

In light of irrefutable redundancy, it is difficult to cite even the most important works that are proposed in the (Polish) literature, and which emerge when attempting to make a synthetic review of the notion in question. I have decided to refer to EFL teaching/ learning works only with the reason for that being twofold: first, I am an English teacher myself and, second, most of the works referred to are, in actual fact, MFL-oriented. On a technical note, the authors' names as per alphabetical order, and only monographs are quoted ${ }^{3}$ : A. Andrychowicz-Trojanowska (2018), M. Dakowska (1987, 1996, 2001/2007, 2003, 2005/2007, 2014, 2015), K. Droździał-Szelest (1997), D. Gabryś Barker (2005), R. Gozdawa-Gołębiowski (2003), H. Komorowska (2003, 2007, 2012), J. Majer (2003), E. Mańczak-Wohlfeld (1992, 1994, 1995), E. Mioduszewska (1992), A. Niżegorodcew (1991, 2007), T. Siek-Piskozub (1994, 1995, 2001, 2002), E. Waniek-Klimczak (1993, 2005, 2009), J. Zybert (1999, 2012).

\section{Contexts of English Teaching and Learning}

The sociolinguistic model of present-day Englishes ${ }^{4}$ developed by B.B. Kachru (1985, 1992), and later by B.B. Kachru/ C.L. Nelson (1996), is best illustrated with a diagram presenting the "inner circle" (representing the six monolingual countries whose inhabitants use the English language as their mother tongue ${ }^{5}$ ), the "outer circle" (consisting of postcolonial countries where English is used as their second language in its institutionalised form) and the "expanding circle" (where the communicative role of English is not formally recognised, it is used as a foreign language on the

\footnotetext{
${ }^{3}$ Taken from the Professors' profiles on their university websites [access: 25.03.2020].

${ }^{4}$ One of the critics of the subject model is Quirk who joins the discussion on passing over the standards and, thus, allowing English to "drift far away from the main linguistic values of standard Global English." (D. Clayton 2011).

${ }^{5}$ E. Lipińska/ A. Seretny (2012) perceive the term "mother tongue" as superior to the concept of "native language" (in the sense: of one's own) which, as they say, stands in contrast to "the other", "not one's own".
} 
economic, cultural or scientific plane) ${ }^{6}$. A. Holliday (1994a, 1994b), in turn, distinguishes between these acronyms: BANA - British (including the Republic of Ireland $^{7}$ ), Australian and North American versus TESEP - tertiary, secondary and primary (education) in reference to language teaching methods; the first refers to private sectors and the second - public ones (of those countries where English is taught as a second or foreign language) while, to give an another example, J. Majer (2003) says that English as a target language can be taught: a. in a monolingual society of its native speakers, b. in a multilingual society (in which English functions as an auxiliary language or intra-community lingua franca), c. in a monolingual or multilingual society (in which English functions as an international lingua franca), d. at any school (where English functions as a subject - without any special status awarded). Needless to say, the latter is also the main focus of attention of the present paper.

In a similar vein, H. Komorowska (2006) draws attention to a conflict that can be observed between the pragmatic goal of calling for unity of the lingua franca - a means of communication between people who speak other mother tongues and intercultural and socio-political languages; this unity, according to her (2006: 111), can only be achieved through a diversity of languages in multicultural contexts. In addition to that, the way any language is taught depends on a number of factors and perspectives such as: socio-cultural, historical, political, educational, economic, technological, linguistic or geographic, to name a few. It should also be borne in mind that "context" in a formalised teaching and learning environment may stand for, inter alia: instructions set in didactic materials (A. Niżegorodcew 2007), any school class (a truly social context indeed) or even a single lesson that, as reported by S. Walsh (2006: 16), might represent a number of interrelated contexts:

[a]ny second language lesson can be viewed as a dynamic and complex series of interrelated contexts, in which interaction is central to teaching and learning. Rather than seeing the classroom as a single social context, as is so often the case, the view taken here is that participants in classroom discourse, teachers and learners, co-construct (plural) contexts. Contexts are constructed through the talkin-interaction in relation to specific institutional goals and the unfolding pedagogic goals of a lesson.

Equally important alike are environmental conditions that can either accelerate or delay the process of language acquisition (R. Ellis 1988). And the distinction, sui generis, between English as one's first language and English as one's second/ additional language can be undermined in a situation where English is detached from its historical roots. What is more, the term "English" can be challenged, too, and replaced by the term "world Englishes" instead. Finally, one can speak of the

\footnotetext{
${ }^{6}$ It is noteworthy that B.B. Kachru $(1985,1992)$ does not indicate any place for pidgin English or creole (P.C. Nichols 1996).

${ }^{7}$ J. Majer (2003) pays attention to the fact that due to the omission of "the Republic of Ireland" in the acronym in question and/ or its inclusion under the letter B (= Britain), BANA becomes a politically troublesome reference.
} 
juxtaposition: "English native speaker" versus "English non-native speaker", too, R. Carter/ D. Nunan (2006) admit.

Bearing the above division in mind, there is no doubt that the idea of English as a pluricentric language which has "more than one acceptable standard and a set of norms for [expressing, M. Ł.] creativity" (B.B. Kachru/ C.L. Nelson 1996: 71) is ultimately recognised, which results in English becoming an international (and intranational) ${ }^{8}$ language (EIL) or lingua franca (ELF). More than that, as pointed out by D. Crystal (2000: 117) nobody owns it either:

[ $t$ ]here comes a point in the spread of a language when no one can be said to own it - in the sense of having a recognized right to direct its development. No one 'owns' English now.

\section{Modern Foreign Languages in Numbers (based on Primary, Lower Secondary and Secondary Schooling in Poland)}

Until $31^{\text {st }}$ August 1999 the 8-year primary school is the first stage of education in Poland after which pupils apply for admission to secondary (4-year general, 5-year technical or 3-year vocational) schools. A reform of the system of education ( $1^{\text {st }}$ September 1999), apart from changes in the national curriculum, introduces new types of schools which offer 6 years of primary education (szkota podstawowa: primary school), 3 years of lower secondary schooling (gimnazjum: gymnasium) and 3 years of (general or specialised) secondary education (liceum: lyceum) or, instead of the latter: 3-4 years of technical secondary education (technikum: technical school) or 2-3 years of vocational secondary education (zasadnicza szkoła zawodowa: vocational school) $)^{9}$. The total number of years of primary and secondary education is from 12 to 15 . At the end of the secondary education cycle students can take the maturity examination - egzamin dojrzałości, i.e. a standardised national secondary school achievement examination, and receive the maturity certificate - świadectwo dojrzałości which enables them to apply for a place at university. Also, as of $1^{\text {st }}$ September 2017 another reform of the education system is introduced resulting in, gradual, liquidation of gymnasiums and immediate restoration of 8-year primary schools, 4-year general secondary schools (lyceums), 5-year technical schools and transformation of vocational schools into professional schools (szkoła branżowa) $\left(1^{\text {st }}\right.$ degree of 3 years; $2^{\text {nd }}-2$ years). Finally, as of the school year 2009/ 2010 there are two important changes introduced in the national curriculum: first, the study of a foreign language as a compulsory school subject begins yet in Year 1 of the primary school ${ }^{10}$ and, second, another foreign language is introduced at the age of 13 (lower

\footnotetext{
${ }^{8}$ Cf.: L.E. Smith (1981).

${ }^{9} 2$ years of complementary lyceum or 3 years of complementary technical school are offered for graduates of vocational schools who want to take their maturity examination.

${ }^{10}$ Subsequent years brought further amendments to the national curriculum as a result of which, in some circumstances, the compulsory age for foreign language schooling is now less than 5 .
} 
secondary school level) - in actual fact, students are to study two foreign languages until the completion of their secondary education, that is until the age of 19.

The percentage of foreign language learners within compulsory classes in the 2016/ 2017 school year could be presented in the following manner: $49.4 \%$ of all pupils in schools for children and teenagers studied one foreign language $51.0 \%$ in the previous school year), two languages were learnt by $46.8 \%$ (in the previous school year: $45.3 \%$ ), no foreign language at all was taught to $3.2 \%$ (in the previous school year $-3.1 \%$; these were usually those pupils who participated in special education programmes). In contrast, three or more foreign languages were studied, as in the previous year, by $0.7 \%$ of students - these were mainly students of general secondary schools who accounted for $61.9 \%$ of all those learning three or more languages. Among the general secondary school students the vast majority (90.8\%) learnt two foreign languages; similar figures referred to the lower secondary school students (92.4\%) and the technical school students (92.6\%). In primary and vocational schools, the majority of students, in accordance with the guidelines: $87.2 \%$ and $94.5 \%$, respectively, studied only one foreign language. In post-secondary schools, during the same school year, $51.9 \%$ of students learnt at least one foreign language, of which $97.5 \%$ learnt indeed one and $2.5 \%$ - two.

The data on students learning foreign languages as compulsory school subjects show that the entire system of primary, lower secondary and secondary schools (including post-secondary schools) was dominated by the teaching of English, which, in the school year 2016/2017, was attended by $95.2 \%$ of all pupils. Second came German (34.5\%), followed by Russian (3.9\%) and French (2.5\%). Spanish was also becoming more popular ( $2.2 \%$ - an increase of 0.4 percentage point).

In primary and lower secondary schools the most popular language learnt was English (95.9\% and 97.3\%, respectively). Similar figures were obtained from general and technical secondary schools: $99.1 \%$ and $98.3 \%$. Yet another year in a row brought an increase (of 1.6 percentage point) in the percentage of students learning English in vocational schools which reached $64.9 \%$, but still remained on a relatively low level compared with other types of schools.

In comparison with the school year 2015/2016, there was an increase (of 0.6 percentage point) to the level of $69.5 \%$ in the popularity of the German language in lower secondary schools, while in technical schools (including arts schools) there was a decrease of 0.5 percentage point. As per post-secondary schools, it remained at a similar level as in the previous school year, that is: $3.5 \%$. In all other types of schools there was a slight decrease in the popularity of the language in question. In secondary schools these figures amounted to: $29.3 \%$ in the case of vocational school students versus $58.6 \%$ - general secondary school students.

Russian was least popular at primary schools (having been chosen by $0.1 \%$ of all foreign language learners). The other figures are - lower secondary schools: $6.5 \%$, vocational schools: $4.8 \%$, technical schools: $9.1 \%$, general secondary schools: $10.1 \%$.

In schools for adults in the 2016/2017 school year, the percentage of students learning English as a compulsory school subject amounted to $68.4 \%$, which constituted a small increase (of 0.2 percentage point) compared with the previous 
school year. The percentage of students learning German increased to $6.0 \%$ (that is by 0.6 percentage point). However, the percentage of those choosing Russian decreased by 0.3 percentage point and oscillated around $1.2 \%$. Teaching other modern foreign languages was occasional ${ }^{11}$.

\section{Conclusions}

Based on the figures presented throughout the course of the previous chapter, one can notice that in the last dozen or so years, the universality of foreign language teaching in Poland has significantly changed. But so has also the standpoint on modern foreign languages teaching and learning expressed by the Council of Europe. Indeed, a change has been implied in the approach to linguistic education per se with the recent introduction of the concept of "plurilingualism" (in contrast to the two already functioning notions, that is: "bilingualism" and "multilingualism"). In actual fact, the purpose of a plurilingual user is no longer to achieve perfection in a given language/ given languages compared to an ideal native user, but, merely, to develop language competence - the latter in accordance with the assumption that

an individual person's experience of language in its cultural contexts expands, from the language of the home to that of society at large and then to the languages of other peoples (whether learnt at school or college, or by direct experience), he or she does not keep these languages and cultures in strictly separated mental compartments, but rather builds up a communicative competence to which all knowledge and experience of language contributes and in which languages interrelate and interact (The common European framework of reference for languages: learning, teaching assessment 2003: 4).

The most noticeable in Poland was the change in the percentage of students subject to compulsory English education which rose to $95.2 \%$ (an increase of 37.0 percentage points compared to the 2001/2002 school year). And since the school year 2011/2012 it has remained level, gaining even a slight increase in the consecutive years. On the other hand, the percentage of students learning German as part of their compulsory classes from the 2005/2006 school year had been dropping slowly with a break in the school years: 2008/2009-2011/2012 when it, in fact, increased by almost 8 percentage points to approximately $39.0 \%$. From the 2012/2013 school year, it began to decline again though and in 2015/2016 it reached 33.7\%. In the 2016/2017 school year, the percentage of students learning German as part of compulsory classes increased by 0.8 percentage point. In comparison with the 2015/2016 school year, the percentage of learners of the Russian language remained level, that is $3.9 \%$. Its popularity, however, has steadily been declining for the last dozen or so years - in the $2001 / 2002$ school year it was studied by $11.4 \%$. The percentage of those studying French or Spanish has, in turn, slightly increased and currently amounts to $2.5 \%$ 11 All statistical data excerpted from the Central Statistical Office document: Education in
(sic!) 2016-2017 school year (pp. 99-104). 
(in the previous school year: $2.4 \%$ ) and $2.2 \%$ (1.8\% in the previous school year), respectively.

Lastly, the popularity of particular foreign languages is regionally diversified, too and although the most common foreign language taught (as part of compulsory school classes) in Poland is English (similarly to the previous school years), there are territorial differences noticeable alike. Thus German dominates in the west whereas Russian - in the east ${ }^{12}$.

\section{Bibliography}

Andrychowicz-Trojanowska, A. (2018), Podręczniki glottodydaktyczne. Strukturafunkcja - potencjat w świetle badań okulograficznych. Warszawa.

Carter, R./D. Nunan (eds.), (2006), The Cambridge Guide to Teaching English to Speakers of Other Languages. Cambridge.

Clayton, D. (2011), English for the English; Englishes for the Rest?, (in:) "EngLangBlog". (URL http://englishlangsfx.blogspot.com/2011/11/englishfor-english-englishes-for-rest.html). [Accessed 3.03.2019].

Crystal, D. (2000), Language Death. Cambridge.

Dakowska, M. (1987), Funkcje lingwistyki $w$ modelach $i$ procesach glottodydaktycznych [Functions of linguistics in glottodidactic models and processes]. Warszawa.

Dakowska, M. (1996), Models of Language Use and Language Learning in the Theory of Foreign Language Didactics. Frankfurt am Main.

Dakowska, M. (2001/ 2007), Psycholingwistyczne podstawy dydaktyki języków obcych [Psycholinguistic foundations of modern foreign languages didactics]. Warszawa.

Dakowska, M. (2003), Current Controversies in Foreign Language Didactics. Warszawa.

Dakowska, M. (2005/2007), Teaching English as a Foreign Language. A Guide for Professionals. Warszawa.

Dakowska, M. (2014), O rozwoju dydaktyki języków obcych jako dyscypliny naukowej [On the development of didactics of modern foreign languages as a scientific discipline]. Warszawa.

Dakowska, M. (2015), In Search of Processes of Language Use in Foreign Language Didactics. Frankfurt am Main.

Droździał-Szelest, K. (1997), Language Learning Strategies in the Process of Acquiring a Foreign Language. Poznań.

Education in (sic!) 2016-2017 school year. Statistical information and elaborations (2017), Central Statistical Office. Warszawa.

\footnotetext{
12 The statistical data are excerpted from the Central Statistical Office document: Education in (sic!) 2016-2017 school year (pp. 99-104).
} 
Edukacja, (in:) "Ministerstwo Edukacji Narodowej”. (URL https://men.gov.pl/). [Accessed 31.3.2019].

Ellis, R. (1988), Classroom Second Language Development. New York.

Gabryś Barker, D. (2005), Aspects of Multilingual Storage, Processing and Retrieval. Katowice.

Gozdawa-Gołębiowski, R. (2003), Interlanguage Formation: a Study of the Triggering Mechanisms. Warszawa.

Grucza, F. (2013), Lingwistyka stosowana. Historia - Zadania - Osiagnięcia. Warszawa.

Grucza, S. (2013), Od lingwistyki tekstu do lingwistyki tekstu specjalistycznego. Warszawa.

Grucza, S. / M. Olpińska-Szkiełko/ M. Płużyczka/ I. Banasiak/ M. Łączek/ A. Bonek/ A. Kaleta/ A. Sztuk (eds.) (2017), Franciszek Grucza. Dzieła zebrane, t. 1-11. Warszawa.

Holliday, A. (1994a), Appropriate Methodology and Social Context. Cambridge.

Holliday, A. (1994b), The House of TESEP and the Communicative Approach: the Special Needs of State English Language Education, (in:) "ELT Journal" 48, 311.

Kachru, B.B. (1985), Standards, Codification and Sociolinguistic Realism: the English Language in the Outer Circle, (in:) R. Quirk/ H.G. Widdowson (eds.), English in the World: Teaching and Learning the Language and Literatures. Cambridge, 11-30.

Kachru, B.B. (1992), World Englishes: Approaches, Issues, and Resources, (in:) "Language Teaching" 25, 1-14.

Kachru, B.B./ C.L. Nelson (1996), World Englishes, (in:) S. Lee McKay/ N.H. Hornberger (eds.), Sociolinguistics and Language Teaching. Cambridge Applied Linguistics. Cambridge, 71-102.

Komorowska, H. (2003), Metodyka nauczania języków obcych [Methodology of teaching foreign languages]. Warszawa.

Komorowska, H., (2006), Teaching English as a Lingua Franca, (in:) J. Zybert (ed.), Issues in Foreign Language Learning and Teaching, Warszawa, 111-123.

Komorowska, H. (2007), Sprawdzanie umiejętności w nauce języka obcego [Assessing skills in foreign language learning]. Warszawa.

Komorowska, H. (2012), O programach $w$ ksztatceniu ogólnym $i$ zawodowym [On curricula in general and vocational education]. Warszawa.

Lipinska, E./ A. Seretny (2012), Między językiem ojczystym a obcym. Nauczanie i uczenie się języka odziedziczonego na przykładzie chicagowskiej diaspory polonijnej. Kraków.

Majer, J. (2003), Interactive Discourse in the Foreign Language Classroom. Łódź.

Mańczak-Wohlfeld, E. (1992), Analiza dekompozycyjna zapożyczeń angielskich $w$ języku polskim [Decomposing analysis of English borrowings in the Polish language]. Kraków.

Mańczak-Wohlfeld, E. (1994), Angielskie elementy leksykalne w języku polskim [English lexical elements in Polish]. Kraków. 
Mańczak-Wohlfeld, E. (1995), Tendencje rozwojowe współczesnych zapożyczeń angielskich $w$ języku polskim [Developing trends of modern English borrowings in the Polish language]. Kraków.

Miodunka, W.T. (2009), Lingwistyka stosowana a nauczanie języka polskiego jako obcego, (in:) "Lingwistyka Stosowana/ Applied Linguistics/ Angewandte Linguistik" 1, 61-80.

Mioduszewska, E. (1992), Conventional Implicature and Semantic Theory. Warszawa.

Nichols, P.C. (1996), Pidgins and Creoles, (in:) S. Lee McKay/ N.H. Hornberger (eds.), Sociolinguistics and Language Teaching. Cambridge Applied Linguistics. Cambridge, 195-217.

Niżegorodcew, A. (1991), Dyskurs interakcyjny a kompetencja komunikacyjna w języku obcym [Interactive discourse and communicative competence in a foreign language]. Kraków.

Niżegorodcew, A. (2007), Input for Instructed L2 Learners. The Relevance of Relevance. Clevedon.

Nocoń, J. (2012), Problemy i dylematy wspótczesnej lingwodydaktyki języka polskiego, (in:) "Lingwistyka Stosowana/ Applied Linguistics/ Angewandte Linguistik" 5, 49-64.

Poland Overview, (in:) "European Commission. EACEA National Policies Platform. Eurydice". (URL https://eacea.ec.europa.eu/nationalpolicies/eurydice/content/poland_en) ${ }^{13}$. [Accessed 1.4.2019].

Siek-Piskozub, T. (1994), Gry i zabawy w nauczaniu języków obcych [Games and plays in teaching foreign languages]. Warszawa.

Siek-Piskozub, T. (1995), Gry, zabawy i symulacje w procesie glottodydaktycznym [Games, plays and simulations in the glottodidactic proces]. Poznań.

Siek-Piskozub, T. (2001), Uczyć się bawiąc. Strategia ludyczna na lekcji języka obcego [Learning by playing. Ludic strategy in a foreign language lesson]. Warszawa.

Siek-Piskozub, T. (2002), Umuzykalnienie glottodydaktyki. Muzyka i piosenka na lekcji jezzyka obcego [Glottodidactics and music. Music and song in a foreign language lesson]. Poznań.

Smith, L.E (ed.) (1981), English for Cross-Cultural Communication. London.

Sokol, J. (2015), Europejska wielojęzyczność, (in:) “Języki obce w szkole. Sięgnij po języki!", 21-27.

Walsh, S. (2006), Investigating Classroom Discourse. Abingdon.

Waniek-Klimczak, E. (1993), The Sociolinguistic Study of Phonetic Parameters in "Polish English": a Case Study of Voice Implementation in the Speech of Polish Immigrants to Great Britain [unpublished doctoral dissertation]. Łódź.

Waniek-Klimczak, E. (2005), Temporal Parameters in Second Language Speech: An Applied Linguistic Phonetics Approach. Łódź.

${ }^{13}$ I would challenge some terms translated from Polish into the English version of the document. 
Waniek-Klimczak, E. (2009), Socio-Psychological Conditioning in ESL Pronunciation: Consonant Voicing in English Spoken by Polish Immigrants to Britain. Włocławek.

Zybert, J. (1999), Errors in Foreign Language Learning. The Case of Polish Learners of English. Warsaw.

Zybert, J. (2012), Efektywność w szkolnej nauce języka obcego. Warszawa. 